\title{
Divorce Stress, Stepfamily Stress, and Depression among Emerging Adult Stepchildren
}

\author{
Kevin Shafer \\ Brigham Young University - Provo, kshafer@byu.edu \\ Todd M. Jensen \\ University of North Carolina at Chapel Hill \\ Erin K. Holmes \\ Brigham Young University - Provo
}

Follow this and additional works at: https://scholarsarchive.byu.edu/facpub

Part of the Family, Life Course, and Society Commons, and the Other Sociology Commons

\section{Original Publication Citation}

Shafer, K., Jensen, T.M.*, \& Holmes, E.K. (2017). "Divorce Stress, Stepfamily Stress, and Depression among Emerging Adult Stepchildren." Journal of Child \& Family Studies, 26(3): 851-862.

\section{BYU ScholarsArchive Citation}

Shafer, Kevin; Jensen, Todd M.; and Holmes, Erin K., "Divorce Stress, Stepfamily Stress, and Depression among Emerging Adult Stepchildren" (2016). Faculty Publications. 4408.

https://scholarsarchive.byu.edu/facpub/4408

This Peer-Reviewed Article is brought to you for free and open access by BYU ScholarsArchive. It has been accepted for inclusion in Faculty Publications by an authorized administrator of BYU ScholarsArchive. For more information, please contact ellen_amatangelo@byu.edu. 


\title{
Divorce Stress, Stepfamily Stress, and Depression among Emerging Adult Stepchildren
}

\author{
Kevin Shafer $^{1} \cdot$ Todd M. Jensen $^{2} \cdot$ Erin K. Holmes ${ }^{3}$
}

Published online: 18 November 2016

(C) Springer Science+Business Media New York 2016

\begin{abstract}
Several decades of research have shown that parental divorce can be a stressful experience for children and may lead to depression and other negative outcomes. Similarly, research has highlighted the stressors often induced by stepfamily formation and their effects on children. Although singular family transitions can exert influence, few studies explore how the combined stress from two family transitions may interact to influence long-term outcomes. Our study addresses this gap by using national data from 1142 respondents who experienced parental divorce and a subsequent transition to stepfamily life. Congruent with prior research, we find that retrospective reports of divorce and stepfamily stress is associated with higher depressive symptoms in emerging adults (18-30 years of age). We also find that stress induced by parental divorce and subsequent stepfamily formation significantly interact to increase depressive symptoms in this population. The research and clinical implications of our findings are discussed.
\end{abstract}

Keywords Stepfamilies $\cdot$ Divorce $\cdot$ Depression $\cdot$ Family stress

Kevin Shafer

kshafer@byu.edu

1 School of Social Work, Brigham Young University, 2190 JFSB, Provo, UT 84602, USA

2 School of Social Work, University of North Carolina-Chapel Hill, 325 Pittsboro Street, Chapel Hill, NC 27599, USA

3 School of Family Life, Brigham Young University, 2092 JFSB, Provo, UT 84062, USA

\section{Introduction}

Stressful life events are strongly correlated with depressive symptoms (e.g., Hammen 2005; Kessler 1997; VrshekSchallhorn et al. 2014). Interpersonal stressors, like divorce and stepfamily formation, are particularly strong predictors of major depressive episodes in both children and adults (see Barrett and Turner 2005 and Sheets and Craighead 2014 for full discussions). Stressful life events can be both discrete and chronic. In one respect, divorce and stepfamily formation are discrete events that take place at a particular point in time. For example, couples are officially divorced when their dissolution becomes final. However, family transitions are also processes that unfold over time. For example, couples often separate or engage in conflict and other interpersonal issues long before divorce. Likewise, couples date and become romantically involved before they form a stepfamily (Amato 2010; Sweeney 2010). The boundaries and roles of divorced-family and stepfamily systems are often negotiated and renegotiated over the course of several years (Papernow 2013). Likewise, stressors associated with divorce and stepfamily formation can be discrete or chronic events. A partial list of such stressors includes moving, a loss of parental support, and economic strain-to name a few (Amato 2000). Importantly, stressors can also result in both negative and positive outcomes for individuals (see Thoits 1995 for review); changing one's perspective on stress by viewing stress as enhancing rather than depleting may have positive impacts (Crum et al. 2013).

Because of the nuanced features of stress following family transitions, this study addresses gaps in the literature by considering the independent and additive effects of divorce and stepfamily stress on depressive symptoms in a sample of emerging adults (age 18-30) who experienced 
both parental divorce and stepfamily formation in their childhood.

Because of the dynamic nature of stress linked to family transitions, the Divorce-Stress-Adjustment (DSA) Perspective (Amato 2000) posits that the influence of the divorce process on individuals is mediated and moderated through a series of stressors and protective factors. In particular, family processes are thought to be more proximally related to child adjustment than family structure (Coleman et al. 2013). Together, this suggests substantial variability in the individual outcomes of children whose parents divorce, with some children faring well in face of family change and others experiencing notable maladjustment. Various stressors help explain this variation, including interpersonal issues like pre-divorce parental conflict (Amato and Sobolewski 2004); attitudes, like whether divorce is a potentially desirable outcome in some families (Amato 2014); the timing of divorce (Kalmijn 2013); or instrumental concerns, like economic instability (Kim 2004). Each could be viewed as either a short-term or long-term stressor, capable of impacting a child's adjustment to the dissolution of the parental relationship. In other words, divorce-related stressors can serve as moments of crisis and/or chronic strains to the individuals who experience them, and some individuals and families possess characteristics or engage in processes that serve to promote, exacerbate, prevent, or attenuate child maladjustment (Amato 2000).

An important aspect of the DSA model is its emphasis on adjustment to divorce as a process that unfolds over time. Thus, events preceding divorce, the divorce itself, and postdivorce experiences are all significant factors in predicting how well individuals adjust to family transitions. For example, a pre-divorce stressor for many children is when fights and conflict were commonplace in their pre-divorce family. These children may adjust to divorce more easily than a child who thought their parents were happily married (Amato 2000). The divorce itself can be particularly stressful for children if the divorce is protracted or disagreeable (Amato and Anthony 2014). A potentially important and common post-divorce stressor is the formation of a stepfamily, where a child lives with a biological parent and the parents' new spouse or partner (Coleman et al. 2013). Up to one-third of American children will experience stepfamily life (Sweeney 2010), and most stepfamilies form following parental divorce as opposed to the death of a parent or non-marital childbearing.

Stepfamily relationships, because of their complexity, can be stressful and difficult to navigate. Complex (where both adults have biological children) and blended (where adults have biological children and a so-called "cement child") stepfamilies may produce higher levels of stress and instability than stepfamilies where children only come from one adult's previous relationship (Kim 2004; Schlee et al. 2009; Tillman 2008). Age at stepfamily formation can also affect stress because stepfamilies formed when children are young tend to experience less stress than families with teenagers and young adults (Sweeney 2010). Stepchildren are often subjected to numerous stressors such as role conflict, stigmatization, the lack of normative family behaviors, coparenting issues, unrealistic expectations and attitudes, strain in step-relationships, disruptions in parentchild relationships, and boundary ambiguity (Cherlin 1978; Ganong and Coleman 1997; Jensen and Howard 2015; Jensen and Shafer 2013; Jensen et al. 2014; Shafer et al. 2013; Stewart 2005). Thus, although many children who experience family transitions fare well, children of divorce and stepchildren are at an elevated risk of experiencing maladjustment-the influence of which can last well into adulthood (see Amato 2010 and Sweeney 2010 for discussions on these topics).

Little is known, however, about how stressful life and family events may or may not work together to impact individuals. Although the divorce and stepfamily literatures show independent links between stress and mental health, little research has addressed whether these stressful life events coalesce to impact individual wellbeing-in this case, mental health (Sheets and Craighead 2014). When considering the combined effects of divorce and stepfamily stress, it is important to consider several issues. First, a comparison of children of divorce to children from biological nuclear families, or stepchildren to biological nuclear families, can mask variability in the experiences of children from divorced households and stepfamilies. It also reflects a deficit-comparison perspective from which researchers have been moving away (Coleman et al. 2000). Not all stepfamilies and divorced families are worse off than all biological nuclear families and not all biological nuclear families are better off than stepfamilies and divorced families (Hetherington and Elmore 2003). Furthermore, addressing the role of stepfamily and divorce stress in mental health outcomes among individuals who experienced these transitions is consistent with a DSA perspective (Amato 2000), and congruent with the growing consensus that family transitions can have a cumulative impact on children's wellbeing (e.g., Cavanagh et al. 2006; Osborne and McLanahan 2007).

Second, current research addresses how specific stressors influence adjustment and personal wellbeing. Overall, these studies suggest complex variations in how individuals experience stressors (McLeod 2012). Several factors including resiliency to stress, baseline subjective wellbeing, expectations about what a family does or how a family acts, and perceptions of stress all play a significant role in how individuals respond to stress and how they adjust to stressors (Amato 2010; Jensen and Bowen 2015). 
On the one hand, addressing specific stressors in the divorce and stepfamily adjustment process is valuable because it allows researchers and practitioners to understand how particular events influence individual outcomes. On the other hand, a global measure of stress may prove valuable in understanding adjustment to divorce and stepfamily formation more holistically. Global measures of stress may be particularly valuable when addressing both the independent and combined effects of divorce and stepfamily stress. Importantly, such measures have proven to be a robust method of assessing wellbeing (Jylhä 2009; Yao and Robert 2008), although we acknowledge that this approach to measuring stress is not without limitations. Also, it is possible that one's perception of general stress related to family transitions more effectively explains links between family transitions and individual well-being than a mere accounting of objective family-structural change.

Third, relatively few studies have addressed how divorce and stepfamily life effects young adults who experienced these family transitions as children. However, prior studies have found that parental divorce can exert influence on children well into adulthood (Cartwright 2006; ChaseLansdale et al. 1995; Cherlin et al. 1998). Similar long-term effects appear among adults who lived in a stepfamily (Cartwright et al. 2009). Furthermore, emerging adulthood (ages 18-30) is an important period of development, when young men and women are making choices about education, career, and family. As a result, emerging adulthood is a period when individuals set their trajectories and launch into adulthood (Arnett 2014). Understanding the factors that impact mental health during this period, particularly those related to family dynamics in childhood, can provide researchers and clinicians with important tools to better understand this developmental stage.

In summary, divorced families and stepfamilies are common in the United States and many children transition through both family forms. Both divorce and stepfamily formation can introduce stressful processes for children. Both family transitions are rife with potential stressors that can impact mental health in both the short- and long-term. Prior studies have shown independent effects of divorce stress (see Amato 2010 for a full review) and stepfamily stress (Jensen et al. 2015) on depression-but no study, to our knowledge, has considered the combined effects of divorce and stepfamily stress on mental health. Moreover, few studies have examined links between children's familytransition stress and mental health outcomes in emerging adulthood. This study addresses these gaps in the literature by considering the independent and additive effects of divorce and stepfamily stress on depressive symptoms in a sample of emerging adults (age 18-30) who experienced both parental divorce and stepfamily formation in their childhood.

\section{Method}

\section{Participants}

Data for this study came from the Stepfamily Experiences Project (STEP), a retrospective data source on stepfamily life collected in 2013. The co-investigators' home institution approved data collection. The data came from a US-based, web-collected quota sample of 1593 emerging adults, aged 18 to 30 at the time of data collection, who lived in a stepfamily for at least one year between the ages of 8 and 18. Although STEP includes individuals who experienced a stepfamily before turning eight years old, we set the lower bound of our age range to eight in order to limit recall bias. Importantly, this age generally aligns with the concrete operational stage of cognitive development (Goswami 2014), potentially making the recall of events (and associated stress) at this age (and onward) more reliable. The retrospective nature of the data means that responses may be shaped by current stepfamily relationships or state of mental health. Participants may also fail to recall their past relationships with complete accuracy, given they are reporting on issues which transpired years before data collection. However, retrospective data is commonly employed in family research and the use of such data, particularly when measuring contemporary outcomes, has merit (Hardt and Rutter 2004). This is useful because STEP was designed specifically to capture variability among individuals who experienced stepfamily life. The guiding principle of the data is that there is substantial variability among stepchildren that is not currently captured by standard data sets. Furthermore, in an effort to minimize the effects of recall bias, we referred to specific times in the lives of the respondent. For example, asking about when the respondent's parents' marriage ended or when the stepfamily formed helps respondents better and more accurately recall their experiences (Schwarz 2007).

\section{Procedures}

Our data are a quota sample, which is less generalizable than a random sample, but is useful when attempting to understand specific characteristics and processes within a subgroup (Gschwend 2005). For example, with this data we are able to understand the mechanisms and unique characteristics of stepfamilies and stepchildren that are not possible in larger, less targeted data sets. The data were collected by Qualtrics, an American research firm, which identified panelists to participate in an online survey, and performed data collection. Respondents were selected among individuals who agreed to participate in online surveys (i.e., an opt-in panel). Panel recruitment takes place through social media, websites, and email recruitment by 
Qualtrics and their research partners. Recruits then form a pool of potential respondents, who are periodically contacted about their potential eligibility for inclusion in a survey based on their demographic data.

The quotas for STEP were fulfilled for racial/ethnic identification and U.S. region of residence. Comparisons between our sample and the US Census estimates from the American Community Survey (2009-2013) indicated that a similar number of respondents graduated college as in the general emerging adult population $(22 \%)$, a similar percentage of respondents were never-married as in the general emerging adult population (65\% in STEP vs. $67 \%$ in the general population), and the racial/ethnic background was also similar (this was the result of quota sampling utilized in STEP). STEP respondents had slightly higher income than the general population and the data is not representative regarding respondent sex. Other statistics were not available because the American Community Survey does not inquire about family structure as a child. Furthermore, national estimates for stepfamily-type (simple, blended, or complex) are not readily available from the Census. The full STEP sample includes an oversample of American Indians-however, we included only a random sample of the oversample to match US Census estimates of the American Indian emerging adult population. This reduced the sample size by 200 individuals. Because only 10 respondents reported being raised in a stepfamily with same-sex parents, analyses were restricted to include only those who reported living in a heterosexual stepfamily. Further, stepfamilies can form through a parent leaving, separating, or divorcing. Prior research suggests that the means by which the separation took place is not significant when one parent becomes nonresidential (Jensen and Shafer 2013). However, the processes between parental separation and a parental death are very different. As a result, 240 individuals who entered a stepfamily because one of their biological parents was deceased were also excluded. Our final analyses were conducted on 1142 participants who experienced a divorce and spent time living in a stepfamily.

Sociodemographic characteristics of the sample are shown in Table 1. About $57 \%$ of participants were female and participant ages ranged between 18 and 30 (mean $=$ 24.2). Modal response options for educational attainment, personal annual income, and past stepfamily annual income were some college, $\$ 20,000-\$ 39,999$, and $\$ 60,000$ $\$ 79,999$, respectively. About $64 \%$ of participants selfidentified as White, with $11 \%$ Black/African-American, $17 \%$ Latino, and $6 \%$ as another racial group or multiracial. About $17 \%$ of participants reported residing in an exclusively cohabiting stepfamily vs. a married stepfamily, $37 \%$ in a complex family (with children from both parents in the home), $17 \%$ in a blended stepfamily (with children from
Table 1 Descriptive statistics for STEP sample $(n=1142)$

\begin{tabular}{|c|c|c|c|c|}
\hline & Mean & SD & Min & Max \\
\hline Depression score & 22.349 & 9.917 & 0 & 60 \\
\hline Divorce stress & 5.472 & 3.120 & 1 & 10 \\
\hline Stepfamily stress & 5.560 & 3.060 & 1 & 10 \\
\hline $\begin{array}{l}\text { Residential biological parent } \\
\text { relationship quality }\end{array}$ & 8.317 & 3.557 & 0 & 12 \\
\hline $\begin{array}{l}\text { Nonresidential biological parent } \\
\text { relationship quality }\end{array}$ & 6.300 & 4.131 & 0 & 12 \\
\hline $\begin{array}{l}\text { Residential stepparent relationship } \\
\text { quality }\end{array}$ & 6.662 & 3.999 & 0 & 12 \\
\hline$\%$ time with nonresidential parent & 24.183 & 26.510 & 0 & 100 \\
\hline Residential stepmother & $29.7 \%$ & & 0 & 1 \\
\hline \multicolumn{5}{|l|}{ Stepfamily characteristics } \\
\hline Age at stepfamily formation & 11.447 & 2.550 & 8 & 18 \\
\hline Years in stepfamily & 7.135 & 3.475 & 0 & 22 \\
\hline Complex stepfamily & 0.371 & & 0 & 1 \\
\hline Blended stepfamily & 0.171 & & 0 & 1 \\
\hline Simple stepfamily & 0.458 & & & \\
\hline Stepfamily income & 4.694 & 2.115 & 1 & 13 \\
\hline Moved because of stepfamily & 0.540 & & 0 & 1 \\
\hline \multicolumn{5}{|l|}{ Demographics } \\
\hline Age & 24.181 & 3.704 & 18 & 30 \\
\hline non-Hispanic Black & $10.8 \%$ & & 0 & 1 \\
\hline Latino & $16.4 \%$ & & 0 & 1 \\
\hline Other racial/ethnic identification & $6.6 \%$ & & 0 & 1 \\
\hline non-Hispanic White & $66.2 \%$ & & 0 & 1 \\
\hline Female & $57.2 \%$ & & 0 & 1 \\
\hline Less than $\$ 20,000$ & $11.6 \%$ & & 0 & 1 \\
\hline$\$ 20,000-\$ 40,000$ & $29.5 \%$ & & 0 & 1 \\
\hline$\$ 40,001-\$ 60,000$ & $28.1 \%$ & & 0 & 1 \\
\hline$\$ 60,001-\$ 80,000$ & $17.0 \%$ & & 0 & 1 \\
\hline$\$ 80,001-\$ 100,000$ & $6.8 \%$ & & 0 & 1 \\
\hline More than $\$ 100,000$ & $7.0 \%$ & & 0 & 1 \\
\hline Catholic & $21.7 \%$ & & 0 & 1 \\
\hline Other religious affiliation & $10.1 \%$ & & 0 & 1 \\
\hline No religious affiliation & $32.0 \%$ & & 0 & 1 \\
\hline Protestant & $36.2 \%$ & & 0 & 1 \\
\hline Less than high school graduate & $8.2 \%$ & & 0 & 1 \\
\hline High school graduate & $18.7 \%$ & & 0 & 1 \\
\hline Some college & $51.8 \%$ & & 0 & 1 \\
\hline College graduate & $21.4 \%$ & & 0 & 1 \\
\hline Married & $27.2 \%$ & & 0 & 1 \\
\hline Cohabiting & $17.0 \%$ & & 0 & 1 \\
\hline Seriously dating & $18.5 \%$ & & 0 & 1 \\
\hline Currently single & $37.3 \%$ & & 0 & 1 \\
\hline
\end{tabular}

both parents' prior relationships and a new child from the current relationship in the home), and $46 \%$ in a simple stepfamily (children from only one parent). 


\section{Measures}

\section{Depression}

The dependent variable was depressive symptoms, as measured by the 20-item Center for Epidemiological Studies-Depression Scale (CES-D), which is reliable across gender, race, and age (Radloff 1977). This scale assesses the frequency of depressed mood, somatic symptoms (like the lack of sleep or changes in eating behavior), and externalized problems in the past seven days. Responses were given on a 4-point Likert-type scale (0-3) with higher scores indicative of more depressive symptoms. Internal reliability for this scale was excellent, with a Cronbach's alpha of 0.94. Per standardized scoring instructions for the scale, all items were summed to produce a continuous measure ranging from 0 to 60 . CES-D scores of 16 or higher are considered clinically significant (Radloff 1977). The mean score of 22 suggests that, on average, emerging adults in stepfamilies are more depressed than the general population (where published mean scores average between 12 and 17). However, rates of depression are significantly higher in emerging adult populations and CES-D scores in our sample are just slightly higher than averages for this group as a whole. Overall, in our sample $52 \%$ of respondents score above 16 on the scale, which is in line with prior studies of emerging adults, which have found between 40 and 50 percent of respondents score above the clinical cutoff (Galambos et al. 2006).

\section{Divorce and stepfamily stress}

The key independent variables measured respondent perceptions of stress caused by divorce and stepfamily formation. The divorce stress question asked: "How much stress did you experience as a result of your parents' relationship ending?" The stepfamily stress question asked: "How much stress did you experience as a result of your stepfamily forming?" Both variables were measured on a continuous scale ranging from $1=$ "None" to $10=$ "Extreme Amount." Response options were discrete.

\section{Control measures}

Several control variables, including both stepfamily and sociodemographic characteristics, were included in the models. Prior research has noted that contact with a nonresidential biological parent can reduce stress associated with divorce and stepfamily formation (Jensen et al. 2015). As a result, contact with the nonresidential biological parent was controlled for with a continuous measure ranging from $0 \%$ (no contact) to $100 \%$ (full contact). We included a dichotomous measure for the sex of the residential stepparent $(0=$ mother, $1=$ father $)$ because the residential stepparent can also play a significant role in child adjustment (King 2009). Prior research also notes the importance of age at divorce and stepfamily formation for adjustment (Jensen and Shafer 2013). Age at divorce may impact how much stress children felt from that family transition and was controlled for with a continuous variable which ranged between 0 and 17. Children raised in stepfamilies from a young age have low levels of stress and tend to see their stepfamily like a biological family (Stewart 2006). Therefore, we included a continuous variable for age at stepfamily formation ranging between 8 and 18. The time spent living with a stepfamily is also important factor in adjusting to stepfamily life. To account for time in the stepfamily, we included a continuous variable that measured the number of years the participants resided in a stepfamily household. Importantly, some respondents continue to live with their stepfamily or lived with their stepfamily past the age of 18 . As a result, this variable can have a value of up to 22 years, if the respondent's stepfamily formed at age 8 and the respondent is currently 30. Stepfamily structure may also be associated with stress. Complex (where both adults have biological children) and blended (where adults have biological children and a so-called "cement child") may be stressful for some children, since interactions in these families are often very different from a stepfamily where only one adult has children from a prior relationship (Kim 2004; Schlee et al. 2009; Tillman 2008). As a result, we controlled for stepfamily structure with dichotomous measures for complex, blended, and simple stepfamily structure.

Other variables have been identified as specific stepfamily stressors and, as a result, should be controlled for. Moving as a result of stepfamily formation has been identified as a significant stressor for stepchildren (Papernow 2013). A dichotomous variable was included for moving as a result of stepfamily formation with $1=$ yes and $0=$ no. Cohabiting stepfamilies tend to be less stable than married stepfamilies (Jensen and Shafer 2013) and were indicated by a dichotomous measure with $1=$ cohabited and $0=$ married. Economic stressors can also be a significant source of stepfamily problems, so we controlled for the stepfamily's annual gross household income. Respondents were asked to recall the overall average income in the stepfamily with an ordinal variable ranging from $1=$ "None," to 13 $=$ "\$300,000 and above." Because respondents were asked about the average income within the stepfamily, some respondents may rely upon more recent income estimates in their assessment. While such a report may be subject to error and recall bias, there is evidence to suggest that adults do a good job of accurately recalling their parents socioeconomic position during childhood (see McKenzie and Carter, 2009 and Batty et al. 2005 for full discussions of this issue). 
While family transitions can be stressful, prior research has noted that they are not guaranteed to be stressful and how much stress stepchildren experience is related to the quality of their relationships with biological and stepparents (Jensen et al. 2015). Thus, any relationship between stress and depression may prove spurious unless the quality of these relationships are controlled for. As a result, we included retrospective reports of parental closeness commonly used in the literature (King 2006; Stewart 2006; King et al. 2014). Individuals were asked how much they agreed, in general, with the following statements about their stepfamily experiences, in general: (1) my (parent type) maintained a close and warm relationship with me; (2) my (parent type) was a good parent to me; and (3) I was able to communicate openly and safely with my (parent type). Respondents were asked the same questions for residential stepparent, residential biological parent, and nonresidential biological parent closeness. The alphas of 0.93, 0.94 and 0.90 indicated good internal consistency for stepparent closeness, nonresident biological parent closeness and resident biological parent closeness, respectively.

Sociodemographic characteristics may affect how individuals perceive their past experiences and report current mental health status (Gilman et al. 2003). Racial/ethnic identification was controlled for with a set of dichotomous variables for Hispanic/Latino, non-Hispanic Black, nonHispanic White (reference), and other racial/ethnic identification. Respondent's gender was included through a dichotomous variable $(1=$ female, $0=$ male). Age was measured with a continuous variable ranging between 18 and 30. Not only does current socioeconomic status influence mental health outcomes, but it has also been linked to assessments of stress (Ursache et al. 2015). As a result, we included a variable for respondent education, which was measured with a set of dichotomous measures for no high school diploma, high school graduate, some college, and at least a bachelor's degree (reference). Finally, the respondent's current marital status was measured with a set of dichotomous measures indicating if the respondent was currently married, cohabiting, dating seriously, and not currently in a relationship (reference).

\section{Data Analyses}

We used ordinary least squares (OLS) regression, a standard method when analyzing the influence of family dynamics on depression (e.g., Evenson and Simon 2005; Frech and Williams 2007). OLS was a preferable method for this paper because the CES-D scale should be treated as a continuous variable (Radloff 1977) and depressive symptoms are commonly conceived on a continuum in the literature (e.g., Evenson and Simon 2005; Shafer and Pace 2015). Tests conducted prior to multiple imputation indicated there were no issues with multicolinearity or heteroskedasticity in our models. There were some missing data on control variables $(<5 \%)$-particularly for measures of current and stepfamily income variables. Even less $(<1 \%)$ data were missing for the dependent variable and the two measures of stress. Little's test $(p=0.861)$ indicated we could assume the data were missing at random (MAR). As a result, we used multiple imputation procedures (Enders 2010) by conducting 20 imputations using the $m i$ command in Stata 13.0. The imputed and non-imputed models had substantively similar results to one another.

We included four models in our analyses. First, we included divorce stress and our control variables while excluding stepfamily stress from the model. In the second model we included stepfamily stress and control variables, but excluded divorce stress. In the third model both measures of stress and all control variables were included. In the final model we introduced an interaction term between divorce and stepfamily stress to address the possibility that the two sources of stress combine to influence the wellbeing of emerging adults raised in a stepfamily.

\section{Results}

In addition to sample characteristics, Table 1 provides the descriptive statistics for our key variables. The mean depression score of 22.40 was higher than the clinical cutoff for the CES-D scale, although scores varied greatly $(S D=10.04)$. Respondents reported similar levels of both divorce and stepfamily stress, with mean scores of 5.47 and 5.55 , respectively.

OLS regression results are reported in Table 2. We first ran a model (divorce stress) that included divorce stress and the control measures. We found that a one-point increase in divorce stress was associated with a 0.587 -point increase in depressive symptoms $(p<.001)$. The standardized coefficient $(\beta=0.184)$, indicated a moderate association between divorce stress and depressive symptoms in emerging adulthood. The second model (stepfamily stress) removed divorce stress from the model, replacing it with stepfamily stress. In this model, we found that a one-point increase in stepfamily stress was associated with a 0.749 -point increase in depressive symptoms $(p<0.001)$. This relationship was moderate in size $(\beta=0.231)$.

Both divorce and stepfamily stress were included, along with control measures, in our third model. Compared to Models 1 and 2, the magnitude of both stress effects was reduced in this model. We found that a one-point increase in divorce stress was associated with a 0.398-point increase in depressive symptoms $(p<0.001)$, while stepfamily stress was associated with a 0.521 point increase in depressive symptoms $(p<0.001)$. The standardized coefficients for 
Table 2 OLS regression estimates for CES-D depression score, averaged over 20 imputations

\begin{tabular}{|c|c|c|c|c|c|c|c|c|}
\hline & \multicolumn{2}{|l|}{ Model 1} & \multicolumn{2}{|l|}{ Model 2} & \multicolumn{2}{|l|}{ Model 3} & \multicolumn{2}{|l|}{ Model 4} \\
\hline & $\begin{array}{l}\text { b } \\
\text { (s.e.) }\end{array}$ & $\beta$ & $\begin{array}{l}\text { b } \\
\text { (s.e.) }\end{array}$ & $\beta$ & $\begin{array}{l}\text { b } \\
\text { (s.e.) }\end{array}$ & $\beta$ & $\begin{array}{l}\text { b } \\
\text { (s.e.) }\end{array}$ & $\beta$ \\
\hline Divorce stress & $\begin{array}{l}0.587 * * * \\
(0.092)\end{array}$ & 0.184 & & & $\begin{array}{l}0.398 * * * \\
(0.103)\end{array}$ & 0.125 & $\begin{array}{l}-0.086 \\
(0.189)\end{array}$ & -0.027 \\
\hline Stepfamily stress & & & $\begin{array}{l}0.749 * * * \\
(0.116)\end{array}$ & 0.231 & $\begin{array}{l}0.521 * * * \\
(0.130)\end{array}$ & 0.159 & $\begin{array}{c}0.102 \\
(0.188)\end{array}$ & 0.031 \\
\hline Divorce stress $\times$ Stepfamily stress & & & & & & & $\begin{array}{l}0.083 * * \\
(0.027)\end{array}$ & 0.259 \\
\hline $\begin{array}{l}\text { Residential biological parent } \\
\text { relationship quality }\end{array}$ & $\begin{array}{l}-0.415^{* * *} \\
(0.097)\end{array}$ & -0.147 & $\begin{array}{l}-0.405 * * * \\
(0.097)\end{array}$ & -0.143 & $\begin{array}{l}-0.375^{* * *} \\
(0.097)\end{array}$ & -0.133 & $\begin{array}{l}-0.366^{* * *} \\
(0.097)\end{array}$ & -0.129 \\
\hline $\begin{array}{l}\text { Nonresidential biological parent } \\
\text { relationship quality }\end{array}$ & $\begin{array}{l}-0.156^{*} \\
(0.073)\end{array}$ & -0.065 & $\begin{array}{l}-0.191 * * \\
(0.073)\end{array}$ & -0.079 & $\begin{array}{l}-0.183 * \\
(0.073)\end{array}$ & -0.076 & $\begin{array}{l}-0.174 * \\
(0.073)\end{array}$ & -0.072 \\
\hline $\begin{array}{l}\text { Residential stepparent relationship } \\
\text { quality }\end{array}$ & $\begin{array}{l}-0.289 * * * \\
(0.084)\end{array}$ & -0.115 & $\begin{array}{l}-0.049 \\
(0.096)\end{array}$ & -0.019 & $\begin{array}{l}-0.100 \\
(0.097)\end{array}$ & -0.039 & $\begin{array}{l}-0.101 \\
(0.096)\end{array}$ & -0.041 \\
\hline$\%$ time with nonresidential parent & $\begin{array}{l}-0.008 \\
(0.011)\end{array}$ & -0.023 & $\begin{array}{l}-0.006 \\
(0.011)\end{array}$ & -0.016 & $\begin{array}{l}-0.009 \\
(0.011)\end{array}$ & -0.025 & $\begin{array}{l}-0.010 \\
(0.011)\end{array}$ & -0.026 \\
\hline Residential stepmother & $\begin{array}{c}0.059 \\
(0.642)\end{array}$ & & $\begin{array}{c}0.005 \\
(0.642)\end{array}$ & & $\begin{array}{c}0.010 \\
(0.638)\end{array}$ & & $\begin{array}{c}-0.023 \\
(0.636)\end{array}$ & \\
\hline Age at divorce & $\begin{array}{c}-0.043 \\
(0.174)\end{array}$ & -0.011 & $\begin{array}{c}-0.043 \\
(0.173)\end{array}$ & -0.052 & $\begin{array}{c}-0.041 \\
(0.037)\end{array}$ & -0.051 & $\begin{array}{c}-0.042 \\
(0.033)\end{array}$ & -0.051 \\
\hline Age at stepfamily formation & $\begin{array}{r}-0.016 \\
(0.089)\end{array}$ & -0.007 & $\begin{array}{c}-0.023 \\
(0.090)\end{array}$ & -0.009 & $\begin{array}{c}-0.041 \\
(0.089)\end{array}$ & -0.018 & $\begin{array}{c}-0.043 \\
(0.089)\end{array}$ & -0.019 \\
\hline Years residing in stepfamily & $\begin{array}{c}0.079 \\
(0.079)\end{array}$ & 0.039 & $\begin{array}{c}0.078 \\
(0.079)\end{array}$ & 0.039 & $\begin{array}{c}0.078 \\
(0.078)\end{array}$ & 0.039 & $\begin{array}{c}0.072 \\
(0.078)\end{array}$ & 0.035 \\
\hline Complex stepfamily ${ }^{a}$ & $\begin{array}{c}-0.083 \\
(0.713)\end{array}$ & & $\begin{array}{c}0.230 \\
(0.709)\end{array}$ & & $\begin{array}{c}-0.065 \\
(0.708)\end{array}$ & & $\begin{array}{c}-0.100 \\
(0.706)\end{array}$ & \\
\hline Blended stepfamily ${ }^{a}$ & $\begin{array}{c}1.431 * \\
(0.893)\end{array}$ & & $\begin{array}{c}1.178^{*} \\
(0.893)\end{array}$ & & $\begin{array}{c}1.290 * \\
(0.888)\end{array}$ & & $\begin{array}{l}1.151 * \\
(0.886)\end{array}$ & \\
\hline Stepfamily income & $\begin{array}{c}-0.270^{*} \\
(0.138)\end{array}$ & & $\begin{array}{c}-0.250 \\
(0.137)\end{array}$ & & $\begin{array}{c}-0.263 \\
(0.137)\end{array}$ & & $\begin{array}{c}-0.274 * \\
(0.136)\end{array}$ & \\
\hline Cohabiting stepfamily & $\begin{array}{l}1.842 * * * \\
(0.714)\end{array}$ & & $\begin{array}{l}2.190 * * \\
(0.698)\end{array}$ & & $\begin{array}{l}1.970 * * \\
(0.698)\end{array}$ & & $\begin{array}{l}1.997 * * \\
(0.694)\end{array}$ & \\
\hline Moved because of stepfamily & $\begin{array}{l}2.024 * * * \\
(0.556)\end{array}$ & & $\begin{array}{l}1.735 * * \\
(0.560)\end{array}$ & & $\begin{array}{l}1.748 * * \\
(0.556)\end{array}$ & & $\begin{array}{l}1.759 * * \\
(0.554)\end{array}$ & \\
\hline Age & $\begin{array}{c}-0.045 \\
(0.088)\end{array}$ & -0.017 & $\begin{array}{c}-0.045 \\
(0.088)\end{array}$ & -0.017 & $\begin{array}{c}-0.041 \\
(0.087)\end{array}$ & -0.015 & $\begin{array}{c}-0.054 \\
(0.087)\end{array}$ & -0.021 \\
\hline Non-Hispanic Black ${ }^{\mathrm{b}}$ & $\begin{array}{c}0.607 \\
(0.924)\end{array}$ & & $\begin{array}{c}0.643 \\
(0.924)\end{array}$ & & $\begin{array}{c}0.664 \\
(0.918)\end{array}$ & & $\begin{array}{c}0.590 \\
(0.915)\end{array}$ & \\
\hline Latino $^{\text {b }}$ & $\begin{array}{c}0.437 \\
(0.760)\end{array}$ & & $\begin{array}{c}0.212 \\
(0.759)\end{array}$ & & $\begin{array}{c}0.356 \\
(0.756)\end{array}$ & & $\begin{array}{c}0.259 \\
(0.753)\end{array}$ & \\
\hline Other racial/ethnic identification ${ }^{\mathrm{b}}$ & $\begin{array}{c}0.651 \\
(1.113)\end{array}$ & & $\begin{array}{c}0.254 \\
(1.113)\end{array}$ & & $\begin{array}{c}0.430 \\
(1.107)\end{array}$ & & $\begin{array}{c}0.503 \\
(1.103)\end{array}$ & \\
\hline Female & $\begin{array}{l}2.160 * * * \\
(0.577)\end{array}$ & & $\begin{array}{l}1.776 * * \\
(0.578)\end{array}$ & & $\begin{array}{l}1.941 * * * \\
(0.576)\end{array}$ & & $\begin{array}{l}1.937 * * * \\
(0.574)\end{array}$ & \\
\hline$\$ 20,000-\$ 40,000^{c}$ & $\begin{array}{c}2.077^{*} \\
(0.949)\end{array}$ & & $\begin{array}{c}1.580 \\
(0.952)\end{array}$ & & $\begin{array}{c}1.732 \\
(0.947)\end{array}$ & & $\begin{array}{c}1.930 * \\
(0.945)\end{array}$ & \\
\hline$\$ 40,001-\$ 60,000^{\mathrm{c}}$ & 1.168 & & 0.610 & & 0.786 & & 0.949 & \\
\hline
\end{tabular}


Table 2 continued

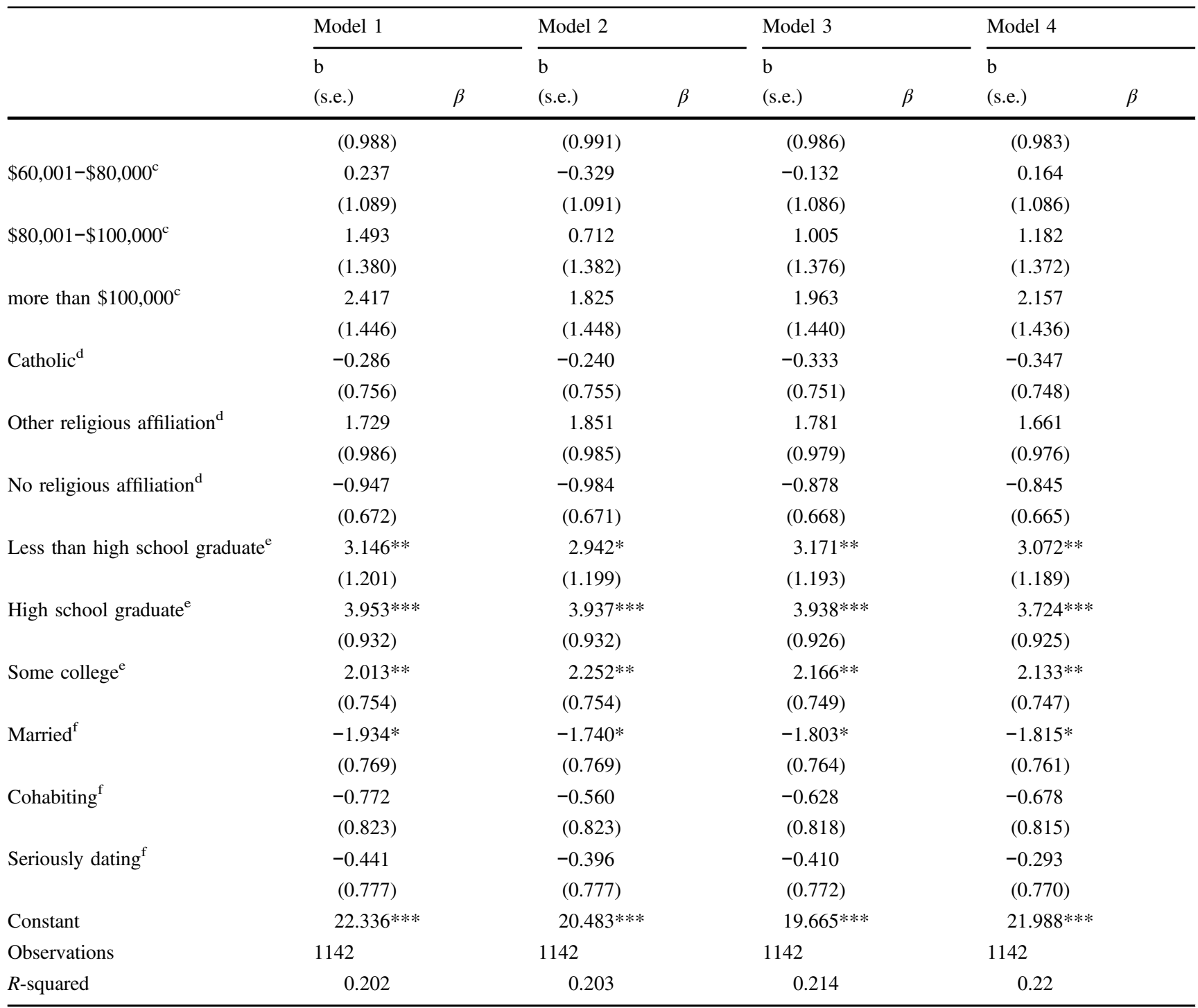

Standardized coefficients are shown for all continuous variables. Standardized coefficients are not appropriate for non-continuous measures $* * * p<0.001, * * p<0.01, * p<0.05$ (two-tailed tests)

${ }^{\text {a }}$ Reference is simple stepfamily

${ }^{\mathrm{b}}$ Reference is non-Hispanic White

${ }^{\mathrm{c}}$ Reference is less than $\$ 20,000$

${ }^{\mathrm{d}}$ Reference is Protestant

${ }^{\mathrm{e}}$ Reference is college graduate

${ }^{\mathrm{f}}$ Reference is currently single

divorce and stepfamily stress were 0.125 and 0.159 , respectively.

In the final model (interactive model) we interacted divorce and stepfamily stress to address the possibility that divorce and stepfamily stress combine to affect depressive symptoms in emerging adults who experienced a stepfamily. This model indicated that both forms of stress interacted to increase depressive symptoms in emerging adults. Figure 1 is presented for ease of interpretation by providing predicted values of depression based on divorce and stepfamily stress. The interaction indicated that high levels of stepfamily stress enhance the effect of divorce stress on depression. Overall, these results suggest that divorce and stepfamily stress can combine to accelerate interactively the level of depressive symptoms in individuals who experience parental divorce and stepfamily formation.

Finally, the control variables had similar effects on depressive symptoms across the models. More specifically, 


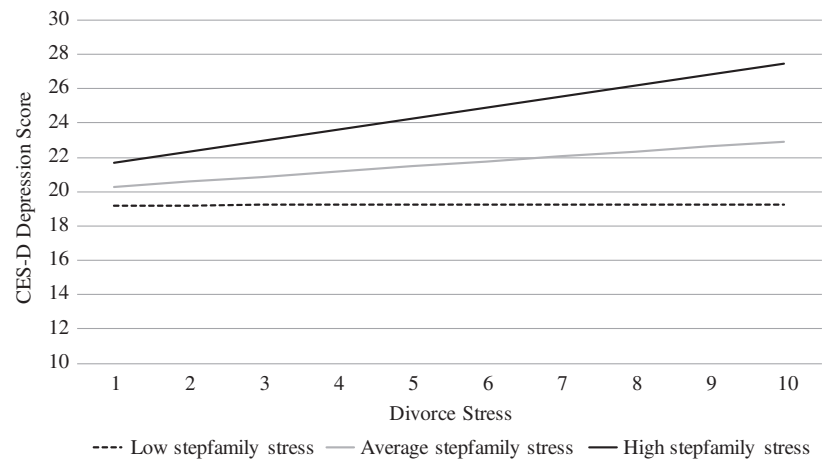

Fig. 1 Predicted CES-D depression score by divorce and stepfamily stress levels.Note: Low stepfamily stress is when stepfamily stress is equal to one, average stress when equal to five, and high stress when equal to 10

we found that a positive relationship with the residential biological parent had the best buffering effect for depressive symptoms, while a positive relationship with the nonresidential biological parent had some effect. We found that residential stepparent relationship quality only had a significant association with depression in Model 1. Many of the stepfamily characteristics did not appear to have an association with depression score. We also found that stepchildren from blended families had slightly higher depression scores than those from simple stepfamilies. Furthermore, cohabiting stepfamilies (compared to married stepfamilies) and stepchildren who moved (compared to those who did not) because of stepfamily formation had higher depression scores. Demographically, women and less educated emerging adults had higher depression scores, while married respondents had lower depression scores than their single counterparts.

\section{Discussion}

Divorce and stepfamily formation are often stressful transitions for both adults and children. Although prior research has considered the independent influences of divorce stress (Amato 2010) and stepfamily stress (Sweeney 2010), few, if any, studies have considered how stress experienced from divorce and stepfamily formation may interactively affect the adults and children who experience such family transitions. There has been an increased focus, however, on the compounding influence of numerous family transitions (e.g., Cavanagh 2008). This literature often addresses how the number of family transitions affects individuals, but fails to consider variability in how these transitions exert influence. A DSA perspective, for example, suggests that several family transitions may have little to no effect if these transitions were not perceived as stressful, whereas the influence may be large when transitions are perceived as particularly stressful. Our paper combines these two perspectives to address a gap in the literature on the potential combined effects of divorce and stepfamily stress. We did this by using retrospective reports of global stress associated with parental divorce and stepfamily formation. We then addressed a long-term mental health outcome potentially associated with these stressors in a sample of 18 to 30-yearold emerging adults.

Consistent with prior research (Lansford 2009), we found that divorce stress is positively associated with depressive symptoms in emerging adults. Although many studies have considered how specific stressors affect individual wellbeing, we used a global measure of stress to capture an overall perception of divorce. A global measure is particularly beneficial because divorce stress stems from a complex equation made up of the many changes related to divorce, including changes in parenting, family stability, economics, and other stressors that can have substantial long-term negative effects for individuals (Amato 2010). The relationship between divorce stress and depression into emerging adulthood is consistent with the chronic strain portion of Amato's (2000) DSA perspective, suggesting that particularly stressful divorce transitions can have a longterm influence on children's wellbeing.

In addition to divorce stress, stressful stepfamily transitions can also have a deleterious influence on mental health in the long-term. Stepfamily life often introduces a number of unique challenges that are likely to induce stress for children, including ambiguous family roles, co-parenting conflict, conflicting family cultures, family relocation, and other issues (Coleman et al. 2013; Sweeney 2010; van Eeden-Moorefield and Pasley 2013). As with divorce stress, we used a global measure of stepfamily stress in an effort to capture the substantial variability in stressors and responses to stress. We found a moderate, positive association between recall of stepfamily stress and depressive symptoms. Thus, as expected by a chronic strain perspective, the stress experienced in stepfamilies appears to be associated with psychological wellbeing in emerging adulthood (Amato 2000).

Most significantly, we considered the possibility that divorce and stepfamily stress combine to negatively influence mental health in emerging adults who experienced both transitions. We were motivated to address this question by the growing body of research which shows that multiple transitions (e.g., married biological family to divorced family to stepfamily) are negatively associated with educational outcomes, physical health, internalized and externalized behavior, and the overall wellbeing of children (Cavanagh and Huston 2006; Fomby and Cherlin 2007; Osborne and McLanahan 2007). Many scholars have theorized these effects are caused by the combined effects of disruptions to the family system, family 
instability, and accompanying stressors (i.e., Amato 2003; Wolfinger 2000). For example, the quality of the relationship between nonresident parent and child is a component of the family system that is correlated with the experience of stress. Our results indicated that the combination of divorce and stepfamily stress had a moderate, positive association with depressive symptoms among emerging adults. Participants who experienced substantial stress from both parental divorce and stepfamily formation reported higher levels of depressive symptoms than participants who found only one of the transitions to be stressful. In the context of low stepfamily stress, the additive influence of divorce stress was essentially nonexistent. More specifically, participants reported stable levels of depression across all levels of divorce stress when the transition to stepfamily life was not perceived as stressful. This suggests that the extent to which family transitions are perceived as stressful marks an important correlate of subsequent depression-a correlate that may be more influential than the transitions themselves. Indeed, stress experienced from multiple family situations may be one reason why family transitions can be so impactful; stress may be an important consideration in any model of family transitions (Amato 2010).

Our findings should be tempered by the various limitations of our paper. First, the retrospective nature of our data may not perfectly align with the experiences of stepchildren as they experienced parental divorce and lived in their stepfamily. For example, retrospective data pertaining to past family relationships can be influenced by the current nature of those relationships. Recall response bias can be particularly problematic if respondents cannot effectively or accurately recall the details of their past relationships. This may be problematic as some respondents are reporting on experiences that transpired years before these data were collected. Further, retrospective accounts can be influenced by an individual's current mental health-an important consideration in the context our study. Nevertheless, retrospective data are not uncommon in family research and the use of such data in understanding the long-term influence of family life is not without merit (Hardt and Rutter 2004). Importantly, perceptions of one's family-of-origin often have a stronger effect on individual outcomes than more objective measures of their actual experiences (i.e., Hetherington 2003; King et al. 2014). Further, the respondent's current mental health status could also affect their responses to questions about stress. For example, a participant who reports relatively high levels of current depression may be more inclined to recall past family transitions as stressful. Because our data is cross-sectional, however, we cannot address this concern methodologically. Similarly, the use of cross-sectional data makes causal inference untenable for our paper.
Finally, the data were derived from a nationally-based quota sample of emerging adults (18-30) who lived in a stepfamily between the ages of 8 and 18 . Quota samples are considered less generalizable than random samples; however, they can be useful when trying to collect data from small or elusive samples (Gschwend 2005). Despite the ubiquitous nature of stepfamilies in the United States, only $10-20 \%$ of respondents in nationally representative data sets, like the National Longitudinal Survey of Youth or the National Study of Adolescent to Adult Health (Add Health), were raised in stepfamilies. This suggests that a random sample of 8000-15,000 would be necessary to accrue the sample size produced by our quota sample. As a result, small samples and the inability to capture variability between stepfamilies are common problems in the stepfamily literature (see King et al. 2014 for a discussion of this issue). Hence, the STEP data were collected using a quota sampling strategy. Nevertheless, we acknowledge that our study findings should be interpreted with caution.

The findings of our study can prove useful in clinical and practice settings. First, clinicians and practitioners should be mindful of the full family history of clients with whom they work. Focusing on the most proximal family transition as a source of stress and maladjustment may be too short-sighted, since pre-existing sources of stress may be exerting influence on individual adjustment over time. Second, children or adolescents with unresolved issues associated with parental divorce may be particularly vulnerable to the additional stress associated with the transition to stepfamily life. Thus, clinicians and practitioners should be mindful of and attend to any issues arising from past family transitions. Third, the family is a dynamic context in which children and adolescents develop. The stress associated with numerous family transitions can pile up, the consequences of which may persist into emerging adulthood. Thus, some emerging adult clients with whom practitioners work may exhibit internalizing problems, such as depression, in response to past stress generated from family-of-origin transitions. Fourth, our findings speak to the importance of prevention. Family life education programs and other resources can inform families about how multiple family transitions can interact to inflict greater amounts of stress and maladjustment; families should be assisted in alleviating stress among family members in response to one family transition prior to the onset of a subsequent transition.

Our findings, similar to many previous studies, suggest there may be unintended consequences associated with parents' decisions to exit and enter various family contexts. Of course, many personal, economic, and social factors play into one's decision to get divorced and enter a new relationship (Shafer and James 2013). Consistent with a systems perspective, individual symptomatology can be viewed as a consequence of maladaptive family dynamics. 
Rather than family transitions being stressful in and of themselves, the resultant family processes are likely operative and influential. Practitioners should attend to any family processes that may be leading to elevated levels of perceived stress among children/adolescents. Practitioners should be keenly aware of the potential family stressors that exist before, during, and after dissolution, as well as when a new family structure forms.

\section{Compliance with Ethical Standards}

Conflict of Interest The authors declare that they have no competing interests.

Human Subjects Statement Data were collected after IRB approval from the first and third authors' university, with protocol approval code \#F120240.

\section{References}

Amato, P. R. (2000). The consequences of divorce for adults and children. Journal of Marriage and the Family, 62, 1269-1287.

Amato, P. R. (2003). Reconciling divergent perspectives: Judith Wallerstein, quantitative family research, and children of divorce. Family Relations, 52, 332-339.

Amato, P. R. (2010). Research on divorce: Continuing trends and new developments. Journal of Marriage and Family, 72(3), 650-666.

Amato, P. R. (2014). The consequences of divorce for adults and children: An Update. Društvena istraživanja-Časopis za opća društvena pitanja (Social Research), 1, 5-24.

Amato, P. R., \& Anthony, C. J. (2014). Estimating the effects of parental divorce and death with fixed effects models. Journal of Marriage and Family, 76(2), 370-386.

Amato, P. R., \& Sobolewski, J. M. (2004). The effects of divorce on fathers and children: Nonresidential fathers and stepfathers. In M. Lamb (Ed.). The role of the father in child development (pp. 341-367). Hoboken, NJ: John Wiley.

Arnett, J. J. (2014). Emerging adulthood: The winding road from the late teens through the twenties. New York: Oxford University Press.

Barrett, A. E., \& Turner, R. J. (2005). Family structure and mental health: The mediating effects of socioeconomic status, family process, and social stress. Journal of Health and Social Behavior, 46(2), 156-169.

Batty, G. D., Lawlor, D. A., Macintyre, S., Clark, H., \& Leon, D. A. (2005). Accuracy of adults' recall of childhood social class: Findings from the Aberdeen Children of the 1950s Study. Journal of Epidemiological Community Health, 59(10), 898-903.

Cartwright, C. (2006). You want to know how it affected me? Young adults' perceptions of the impact of parental divorce. Journal of Divorce \& Remarriage, 44(3-4), 125-143.

Cartwright, C., Farnsworth, V., \& Mobley, V. (2009). Relationships with stepparents in the life stories of young adults of divorce. Family Matters, 82, 30-37.

Cavanagh, S. E. (2008). Family structure history and adolescent adjustment. Journal of Family Issues, 29(7), 944-980.

Cavanagh, S. E., \& Huston, A. C. (2006). Family instability and children's early problem behavior. Social Forces, 85(1), 551-581.

Cavanagh, S. E., Schiller, K. S., \& Riegle-Crumb, C. (2006). Marital transitions, parenting, and schooling: Exploring the link between family-structure history and adolescents' academic status. Sociology of Education, 79(4), 329-354.
Chase-Lansdale, P. L., Cherlin, A. J., \& Kiernan, K. E. (1995). The long-term effects of parental divorce on the mental health of young adults: A developmental perspective. Child Development, 66(6), 1614-1634.

Cherlin, A. (1978). Remarriage as an incomplete institution. American Journal of Sociology, 84(3), 634-650.

Cherlin, A. J., Chase-Lansdale, P. L., \& McRae, C. (1998). Effects of parental divorce on mental health throughout the life course. American Sociological Review, 63(2), 239-249.

Coleman, M., Ganong, L., \& Fine, M. (2000). Reinvestigating remarriage: Another decade of progress. Journal of Marriage and Family, 62(4), 1288-1307.

Coleman, M., Ganong, L., \& Russell, L. (2013). Resilience in stepfamilies. In D. Becvar (Ed.), Handbook of family resilience (pp. 85-103). New York: Springer.

Crum, A. J., Salovey, P., \& Anchor, S. (2013). Rethinking stress: The role of mindsets in determining the stress response. Journal of Personality and Social Psychology, 104(4), 716-733.

Enders, C. K. (2010). Applied missing data analysis. New York, NY: The Guilford Press.

Evenson, R. J., \& Simon, R. W. (2005). Clarifying the relationship between parenthood and depression. Journal of Health and Social Behavior, 46(4), 341-358.

Frech, A., \& Williams, K. (2007). Depression and the psychological benefits of entering marriage. Journal of Health and Social Behavior, 48(2), 149-166.

Ganong, L. H., \& Coleman, M. (1997). How society views stepfamilies. Marriage \& Family Review, 26(1-2), 85-106.

Gschwend, T. (2005). Analyzing quota sample data and the peerreview process. French Politics, 3(1), 88-91.

Hammen, C. (2005). Stress and depression. Annual Review of Clinical Psychology, 1, 293-319.

Hardt, J., \& Rutter, M. (2004). Validity of adult retrospective reports of adverse childhood experiences: Review of the evidence. Journal of Child Psychology and Psychiatry, 45(2), 260-273.

Hetherington, E. M. (2003). Intimate pathways: Changing patterns in close personal relationships across time. Family Relations, 52, 318-331.

Hetherington, E. M., \& Elmore, A. M. (2003). Risk and resilience in children coping with their parents' divorce and remarriage. In S. S. Luthar (Ed.), Resilience and vulnerability: Adaptation in the context of childhood adversities (pp. 182-212). Cambridge, UK: Cambridge University Press.

Fomby, P., \& Cherlin, A. J. (2007). Family instability and child wellbeing. American Sociological Review, 72(2), 181-204.

Galambos, N. L., Barker, E. T., \& Krahn, H. J. (2006). Depression, self-esteem, and anger in emerging adulthood: Seven-year trajectories. Developmental Psychology, 42(2), 350-365.

Gilman, S. E., Kawachi, I., Fitzmaurice, G. M., \& Buka, S. L. (2003). Family disruption in childhood and risk of adult depression. American Journal of Psychiatry, 160(5), 936-946.

Goswami, U. (2014). Cognition in Children. New York: Psychology Press.

Jensen, T. M., \& Bowen, G. L. (2015). Mid- and late-life divorce and parents' perceptions of emerging adult children's emotional reactions. Journal of Divorce \& Remarriage. doi:10.1080/ 10502556.2015.1046795.

Jensen, T. M. \& Howard, M. O. (2015). Perceived stepparent-child relationship quality: A systematic review of stepchildren's perspectives. Marriage \& Family Review, online ahead of print. doi:10.1080/01494929.2015.1006717.

Jensen, T. M., \& Shafer, K. (2013). Stepfamily functioning and closeness: Children's views on second marriages and stepfather relationships. Social Work, 58(2), 127-136.

Jensen, T. M., Shafer, K., \& Holmes, E. K. (2015). Transitioning to stepfamily life: The influence of closeness with biological parents 
and stepparents on children's stress. Child \& Family Social Work. Online ahead of print. doi:10.1111/cfs.12237.

Jensen, T. M., Shafer, K., \& Larson, J. H. (2014). (Step)parenting attitudes and expectations: Implications for stepfamily functioning and clinical intervention. Families in Society: The Journal of Contemporary Social Services, 95(3), 213-220.

Jylhä, M. (2009). What is self-rated health and why does it predict mortality? Towards a unified conceptual model. Social Science \& Medicine, 69(3), 307-316.

Kalmijn, M. (2013). Long-term effects of divorce on parent-child relationships: Within-family comparisons of fathers and mothers. European Sociological Review, 29(5), 888-898.

Kessler, R. C. (1997). The effects of stressful life events on depression. Annual Review of Psychology, 48, 191-214.

Kim, H. J. (2004). Family resources and children's academic performance. Children and Youth Services Review, 26(6), $529-536$.

King, V. (2006). The antecedents and consequences of adolescents' relationships with stepfathers and nonresident fathers. Journal of Marriage and Family, 68(4), 910-928.

King, V. (2009). Stepfamily formation: Implications for adolescent ties to mothers, nonresident fathers, and stepfathers. Journal of Marriage and the Family, 71(4), 954-968.

King, V., Thorsen, M. L., \& Amato, P. R. (2014). Factors associated with positive relationships between stepfathers and adolescent stepchildren. Social Science Research, 47, 16-29.

Lansford, J. E. (2009). Parental divorce and children's adjustment. Perspectives on Psychological Science, 4(2), 140-152.

McKenzie, S. K., \& Carter, K. N. (2009). Are retrospective measures of childhood socioeconomic position in prospective adult health surveys useful? Australasian Epidemiologist, 16(3), 22-24.

McLeod, J. D. (2012). The meanings of stress expanding the stress process model. Society and Mental Health, 2(3), 172-186.

Osborne, C., \& McLanahan, S. (2007). Partnership instability and child well-being. Journal of Marriage and Family, 69(4), 1065-1083.

Papernow, P. L. (2013). Surviving and thriving in stepfamily relationships: What works and what doesn't. New York: Routledge.

Radloff, L. S. (1977). The CES-D scale a self-report depression scale for research in the general population. Applied Psychological Measurement, 1(3), 385-401.

Schlee, B. M., Mullis, A. K., \& Shriner, M. (2009). Parents social and resource capital: Predictors of academic achievement during early childhood. Children and Youth Services Review, 31(2), 227-234.

Schwarz, N. (2007). Retrospective and concurrent self-reports: The rationale for real-time data capture. In A. Stone, S. S. Shiffman, A. Atineza, \& L. Nebeling (Eds.), The science of real-time data capture: Self-reports in health research (pp. 11-26). New York: Oxford University Press.

Shafer, K., \& James, S. L. (2013). Gender and socioeconomic status differences in first and second marriage formation. Journal of Marriage and Family, 75(3), 544-564.

Shafer, K., \& Pace, G. T. (2015). Gender differences in depression across parental roles. Social Work, 60(2), 115-125.

Shafer, K., Jensen, T., Pace, G., \& Larson, J. (2013). Former spouse ties and post-divorce relationship quality: Relationship effort as a mediator. Journal of Social Service Research, 39(5), 629-645.

Sheets, E. S., \& Craighead, W. E. (2014). Comparing chronic interpersonal and non-interpersonal stress domains as predictors of depression recurrence in emerging adults. Behaviour Research and Therapy, 63, 36-42.

Stewart, S. D. (2005). Boundary ambiguity in stepfamilies. Journal of Family Issues, 26(7), 1002-1029.

Stewart, S. D. (2006). Brave new stepfamilies: Diverse paths toward stepfamily living. Thousand Oaks, CA.

Sweeney, M. M. (2010). Remarriage and stepfamilies: Strategic sites for family scholarship in the 21 st century. Journal of Marriage and Family, 72(3), 667-684.

Thoits, P. A. (1995). Stress, coping, and social support processes: Where are we? What next? Journal of Health and Social Behavior, 53-79.

Tillman, K. H. (2008). Coresident sibling composition and the academic ability, expectations, and performance of youth. Sociological Perspectives, 51(4), 679-711.

Ursache, A., Noble, K. G., \& Blair, C. (2015). Socioeconomic status, subjective social status, and perceived stress: Associations with stress physiology and executive functioning. Behavioral Medicine, 41(3), 145-154

van Eeden-Moorefield, B., \& Pasley, K. (2013). Remarriage and stepfamily life. In G. W. Peterson, \& K. R. Bush (Eds.), Handbook of marriage and the family (pp. 517-546). New York: Springer.

Vrshek-Schallhorn, S., Wolitzky-Taylor, K., Doane, L. D., Epstein, A., Sumner, J. A., Mineka, S., \& Adam, E. K. (2014). Validating new summary indices for the Childhood Trauma Interview: Associations with first onsets of major depressive disorder and anxiety disorders. Psychological Assessment, 26(3), 730-740.

Wolfinger, N. H. (2000). Beyond the intergenerational transmission of divorce do people replicate the patterns of marital instability they grew up with? Journal of Family Issues, 21(8), 1061-1086.

Yao, L., \& Robert, S. A. (2008). The contributions of race, individual socioeconomic status, and neighborhood socioeconomic context on the self-rated health trajectories and mortality of older adults. Research on Aging, 30(2), 251-273. 